\title{
Study on Impact Factors of Local Colleges and Universities Graduate Education Quality
}

\author{
Xiaolan He, Junrong Zhou \\ WuYi University, Jiang Men, Guang Dong, China
}

\begin{abstract}
The quality of graduate education is to promote the all-round development of graduates and meet the needs of society. Based on the systems management theory and hierarchy of needs theory, this paper builds a relation model of impact factors of engineering graduate education quality in local colleges and universities, and analyzes the factors' relations and functions from seven-dimensions, and for engineering graduate education quality assurance, proposes local colleges and universities on talent positive effect on the local society orientation, correctly handling the relations between local government and local enterprises and institutions, establishing a long-term graduated graduate students liaison mechanism, reforming graduate cultivation mechanism, strengthening tutor team construction, establishing quality supervision mechanism.

KEYWORD: Systems management theory; Hierarchy of needs theory; Local colleges and universities; Engineering graduate education; Quality; Impact factor
\end{abstract}

\section{INTRODUCTION}

"National Long-term Education Reform and Development Plan (2010-2020) " has put forward to improve the higher education quality as a core task of reform and establish a scientific concept of quality, promoting the all-round development of students and meeting the needs of society as a measure fundamental criterion of education quality, these pointed out a clear direction for the future of graduate education. The local colleges and universities are an important part in the graduate education system, with a very obvious regional social service characteristic. Improving engineering graduate education quality in local colleges and universities is a great significance. The engineering graduate training objective in local colleges and universities is promoting the all-round development of engineering graduates and meeting the social needs as a fundamental cultivating high-level applied talent with a strong innovation capability to serve the region's economic construction and scientific and technological progress.[1] From the perspective of management, this paper researches social factors' dependencies of local higher education for exploring engineering graduate education quality assurance in local colleges and universities.

\section{BUILDING RELATION MODEL OF QUALITY IMPACT FACTORS}

\subsection{Application of management theory and thinking}

\subsubsection{Application of management theory to local higher education and thinking}

The system management school thought, organization is an open system being composed of several elements, affected by and in turn affect the environment; organization is a system not only in itself, it is also a sub- system of a broader social system, which made dynamic equilibrium in the interaction with the environment; organization accepts various inputs of energy, information, materials, etc. from the external environment, after the conversion, output products in the form of goods or service to the external environment.[2] This view puts the organization as an open system, that is, putting a variety of factors of the organization's internal and external environment as an organic whole, and thinking the organization is in access to development in constant interaction with the environment and only under the overall pattern in open systems, the exact relation between variables within and outside the organization can be identified in order well.

Local colleges and universities is an organization system under a particular social environment, their sponsoring is social activities with fully considering the regional social environmental conditions and 
having significant impact on regional social environment. They provide talents and intellectual support for the society through investment in software and hardware facilities by a set of social resources. Therefore, only in the open systems mode, the state can be in a relatively balance and stable among the various organization systems and between organization systems and the external social environment.[1]

\subsubsection{Hierarchy of needs theory to motivate acts and thinking}

Maslow's hierarchy of needs theory divides demand into the physiological needs, safety needs, social needs, esteem needs and self-actualization needs, five kinds of needs are followed by a lower level to a higher level.[2] One of its basic arguments is that people need is depended on what he has got, what is missing, only the yet met needs can really affect people's demand acts. It interprets that the yet met needs can motivate people acts.[3]

Since different experience, different people' yet met needs exists respective differences. The extent of five levels demand for the social behavior people varies with changing of time, place and contact things, and the changes create new yet met needs. The needs are met in past stage and the new yet meet needs have appeared at this stage. Appearing alternately of five kinds of needs met or yet met needs inspires the social behavior people continue to pursue new goals. All yet met needs produce from society and will be achieved in society. Engineering graduate education in local colleges and universities involves every college and university teacher (In this paper, it refers to graduate tutor, teacher taught graduate courses, and it is referred to teacher.), graduate student (In this paper, it refers to graduate student studying in local colleges and universities), graduated graduate student (In this paper, it refers to graduate student being graduated from local colleges and universities, and it is referred to graduate in the third part.), on the social behavior individual concerned, their yet met needs are the motivations they are active in society.

\subsection{Building relation model of quality impact factor}

\subsubsection{Building model}

Social factors of local higher education include related social institutions and social behavior people having close relation with these social institutions. The talent positive effect on the local society is the relevant product of higher education. Moral, intellectual, physical, and aesthetic aspects of talent affecting society and promoting social development are called social positive effect of talent. In the overall system management theory and Maslow's hierarchy of needs theory, building a relation model of impact factors of engineering graduate education quality in local colleges and universities with seven factors: talent positive effect on the local society (1), local colleges and universities (2), graduate students (3), teachers (4), local government (5), local enterprises and institutions (6), graduated graduate students (7)). It is shown in Figure 1.

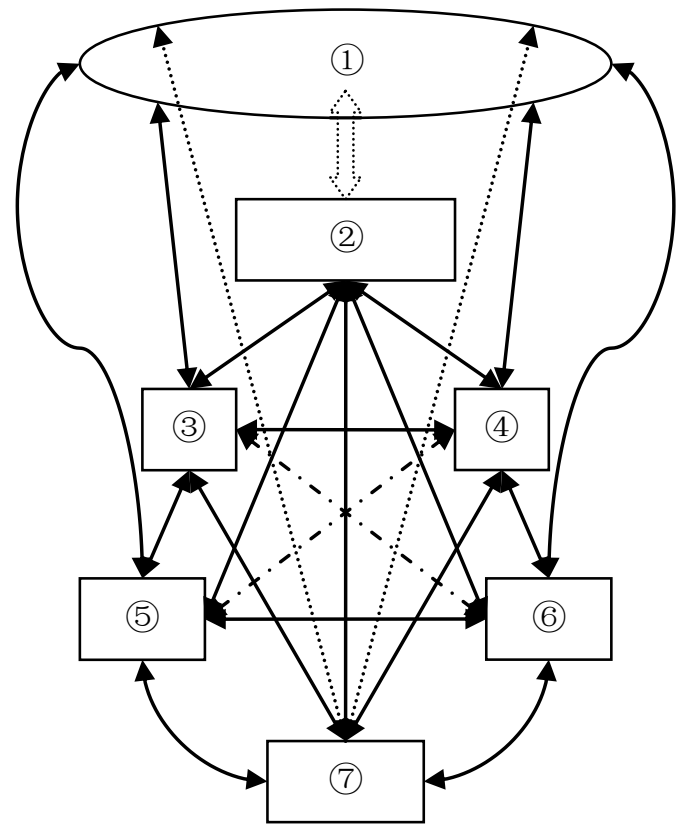

Figure1. Relation model of impact factors of engineering graduate education quality in local colleges and universities

\subsubsection{Characteristics of model}

In the relation model, factor(2) is the core factor, factor(1) is both the guide and the goal and brought to the front, and its survival hinges on the other six factors. The bidirectional connection and arrows indicate a correlation between factors and all factors form a community of interests. Model such as cup, it heralds that the engineering graduate education in local colleges and universities is growing in the coordination with each other and interests in seeking common.

\section{STUDY ON IMPACT FACTORS OF QUALITY}

In the engineering graduate education quality assurance activities, local colleges and universities is core subject, local government, local enterprises and institutions are derivative subjects, teachers, graduate students, and graduates not only directly have an effect, but have an indirect effect through derivatives on the local colleges and universities. In the relation model, three factors form a triangle. Based on the stability principle of triangles, factors in their triangle are stable and related. Choose seven factor triangle dimensions, as follows, analyze the factors' relations and functions. 


\subsection{Local colleges and universities-Local government-Local enterprises and institutions}

The coordinated development of local higher education and the local economic construction is the foundation of social harmony and progress. Financial support of local government and talent needs of local enterprises and institutions is the sponsoring basis of local colleges and universities. Mission and responsibility of local colleges and universities are to promote local economic and social development, and committed to resolve the real problems facing the region's economic and social development. Local colleges and universities provide talent and intellectual support for local enterprises and institutions. Local government investment playing a greater benefit in the expansion of human capital accumulation and enhancing the competitiveness of the region relies on local colleges and universities to bring up high-level applied talent.

In view of social functions, local government, local enterprises and institutions are the main demand subjects of engineering graduate education in local colleges and universities, the three must be interdependent and coordinated development.

In view of quality control, local governments, enterprises and institutions are the main external quality assurance for engineering graduate education quality in local colleges and universities.

\subsection{Local colleges and universities- Graduate students - Teachers}

Graduate students are learners, but also educated, and demanders of individuality development needs. Different gender, hobbies, major, parents' occupation, etc. lead to the differences of their individuality development needs during the period of learning. The needs met is to promote graduate students all-round development as a precondition.

Local colleges and universities are talent output agencies, they also are creators of harmony, excellent teaching and research environment, and the discoverers and behavior motivators of the teachers and graduate students' yet met needs.

Teachers are disseminators of knowledge and provide direct teaching and research services to graduate students. Teachers engage in teaching and scientific researches, is also the need of selfrealization. The teachers teaching and research level symbolizes academic reputation and service levels of local colleges and universities. Graduate students in moral, intellectual, physical, and aesthetic aspects of development, in a sense, symbolizes the guidance level of teachers and the local colleges and universities management level.

\subsection{Local colleges and universities- Graduate students-Graduates}

Graduates are talent working in local enterprises and institutions. From local colleges and universities to society, through the course of study, social practice, research, writing thesis, they can transfer their accumulated learning and work experience to graduate students. Graduate students learn graduates advantages and adjust their career expectations.

Graduates are media carrier of local colleges and universities. They spread good information of graduates and Alma Mater to society, so thus can attract high quality students and reduce the disadvantage brand influence barriers to employment of graduate students.

\subsection{Local colleges and universities - Teachers- Graduates}

Graduates are important measure of talent positive effect on the local society. The local colleges and universities through interviews, questionnaire survey graduates, understand local enterprises and institutions' requirement of technology and talent; understand their work details in local enterprises and institutions, in particular, their professional development; and ask for the management, teaching, scientific research and guide improvement opinions for the local colleges and universities.

The local colleges and universities feedback the information and opinions to teachers, it is conducive to the teachers to improve teaching methods, and conducive to the tutors to create new guidance idea and try to find the best way to cultivate high-level applied talents.

\subsection{Graduate students-Local government-Local enterprises and institutions}

Making scientific researches and practice activities at the local enterprises and institutions, on the one hand, graduate students display their talents and the individual ability is measured through his role and impact on enterprises and institutions, on the other hand, collective strength changes the technology producing status quo of local enterprises and institutions to some extent, and these make impacts on local social economic construction and technology progresses, and thus influences government decision-making, and then the government decisions influence local enterprises and institutions until graduate individuals. Through social practice, graduate students understand the needs of local society, and decide their own direction of development for their careers. These provide an objective basis for the practice management of local colleges and universities. 


\subsection{Teachers- Local government-Local enterprises and institutions}

Teachers are the main force to cultivate talents and also the backbone of local higher education to provide research services for the local enterprises and institutions. Local enterprises and institutions provide research and practice places for tutors to train graduate students. Tutors direct graduate students to choose actual production research topics and write practical value thesis, and help local enterprises and institutions solve practical problems.

Through personal efforts, teachers can win research cooperation credits with local enterprises and institutions and strive for more investment in education and more horizontal research funding for local colleges and universities. The value of teachers are recognized by local government and local enterprises and institutions, thus their individual social needs, esteem needs and self-actualization needs are met.

\subsection{Graduates- Local government-Local enterprises and institutions}

Graduates are human capital for local government and local enterprises and institutions. When multidisciplinary professional human capital accumulation to a certain extent, its role will significantly change the backwardness of local enterprises and institutions and promote the local social economic construction and scientific and technological progresses, and affect local government making decisions in multiple perspectives of allocation of resources, industry clusters, industrial chain, etc. thereby, promote the local colleges and universities to look at the development orientation of higher education to adapt to the regional economic development needs, and reasonably adjust disciplines layout and the enrollment plan of graduate education.

\section{RECOMMENDATIONS}

For engineering graduate education quality assurance, proposes local colleges and universities on talent positive effect on the local society orientation taking the following measures:

1. Correctly handle the relations between local colleges and universities, local government, and local enterprises and institutions; the needs of accommodating and promoting the region's economic and social development as a precondition, cultivate high-level applied talent for local enterprises and institutions; actively seek the support of local governments and enterprises and institutions to ensure the investment in education.

2. Establish a long-term graduated graduate students' liaison mechanism; Graduate Student Alumni Association as a bridge, strengthen communication with local enterprises and institutions, promote teachers and graduate students communicating with graduated graduate students; use practice education management to ensure training graduate students' practical value.

3. Reform graduate cultivation mechanism. Establish tutor accountability and tutor funding system, and perfect graduate grants policy system; motivate graduate students to scientific research with great concentration, meet the individual development needs of graduate students, promote the all-round development of graduate students.

4. Strengthen the construction of the tutor team. Form teachers' good ethics, innovate guidance idea; perfect tutor selection mechanism, promote tutors to improve personal accomplishment and improve scientific research ability; establish tutor incentive mechanism, motivate tutors to realize individual value in cultivating high-level applied talent for local economic and social construction.

5. Establish quality supervision mechanism. Assess teachers' teaching, research, guidance levels, assess thesis level of graduated graduate students, and publicize the assessment results regularly; establish local government, enterprises and institutions as the leading monitoring agencies off campus to supervise local colleges and universities internal quality assurance activities.

\section{ACKNOWLEDGEMENTS}

The research is supported by Guangdong Province Degrees and Graduate Education Reform Project "Exploring Engineering Graduate Education Quality Assurance System in Local Colleges and Universities" (11JGXM-MS29)

\section{REFERENCES}

[1] Xiaolan He etc.2014.An Exploration of Engineering Graduate Education Quality Assurance at Local Colleges and Universities. Journal of WuYi University (social science edition) (1): 87-88

[2] Chong Shao.1996.Introduction to Management. Sun Yatsen University press: 61-62, 300-302

[3] Hongyi Zhang. 2011. Research on the Characteristics of Personal Needs on Postgraduate Education. Xiangtan University: 14 